\title{
An Evaluation of Tsunami Hazard Modeling in Gunungkidul Coastal Area using UAV Photogrammetry and GIS. Case Study: Drini Coastal Area
}

\author{
Muh Aris Marfai ${ }^{1, *}$, Hendy Fatchurohman ${ }^{2}$, and Ahmad Cahyadi ${ }^{1}$ \\ ${ }^{1}$ Dept. of Environmental Geography, Faculty of Geography, Universitas Gadjah MadaYogyakarta, Indonesia \\ ${ }^{2}$ Dept. of Geographic Information Science, Faculty of Geography, Universitas Gadjah Mada, Yogyakarta, Indonesia \\ ${ }^{3}$ Master Program in Planning and Management of Coastal Area and Watershed, Universitas Gadjah Mada, Yogyakarta, Indonesia
}

\begin{abstract}
In recent years, Tourism activities in Gunungkidul Coastal Area rapidly increased. A large number of tourists visiting the coast considered as elements at risk that are exposed to tsunami hazards. Disaster infrastructures provided by the government e.g. hazard maps, evacuation routes, and locations for assembly points are inadequate. The tsunami inundation models provided by the government are based on national topographic maps (RBI), resulting in inaccurate models. DEM generation using UAV Photogrammetry produces high spatial resolution data that results in more accurate tsunami inundation model. The results of the model using UAV photogrammetry are also capable of producing several inundation scenarios and determine the safe areas that can be used for temporary evacuation sites. The use of UAV photogrammetry for tsunami inundation models provides many advantages including low cost and accurate model results. Evaluation of hazard maps and assembly points using UAV Photogrammetry modeling lead to more effective and less time-consuming on the evacuation process.
\end{abstract}

Keywords: Unmanned Aerial Vehicle; Hazard; Tsunami; Loss Estimation.

\section{Introduction}

Tsunami is one of the disasters that have a serious impact on coastal communities [1,2]. The southern coast of Java is prone to tsunami because of its location that adjacent to the subduction zone [3-6]. The Gunungkidul coast, as is located in the southern coast of Java is directly adjacent to the Indo-Australian subduction zone that leads to high tsunami hazard potential. Subduction zones will cause potential earthquakes, while earthquakes are the main cause of tsunamis in Indonesia [7]. The development of tourism in this regency contributes to increased vulnerability to tsunamis. The growing number of tourists over time has raised the vulnerability level as more people are exposed to danger

Intensive tourism activities on the coast of Gunungkidul led to the need for adequate tsunami evacuation management. Tsunami disaster mitigation is a comprehensive process. It includes tsunami evacuation, which considers many factors in its design. The tsunami evacuation process is a process in minutes that each individual must evacuate themselves in safe areas [8]. This condition must be supported by the existence of effective evacuation routes and accessible locations for assembly points. Vertical Tsunami Evacuation (TVE) is an option as a location for sheltering in place during the tsunami occurrence $[8,9]$. As a short yet most determining action taking place within minutes after a tsunami event, evacuation must be carefully planned.

Studies on coastal disasters can rely on the combination of hydrological modeling and Geographic Information System (GIS) [10-12]. Based on the tsunami inundation model, the area that prone to tsunami hazards can be determined. The inundation models are also able to be generated into different tsunami height scenarios. According to tsunami inundation model by [13], most of Gunungkidul coasts are susceptible and vulnerable to tsunami hazard, that leads to high risk of tsunami disaster. This study aimed to perform a UAV-based topographical mapping for tsunami inundation modeling. This model was further used to determine the optimum location for vertical evacuation. The modeling results are expected to propose an alternative evacuation system that particularly considers vertical instead of horizontal evacuation.

\section{Study Area}

Increased tourism activity in Gunungkidul multiplies the number of people exposed to the threat of tsunamis. In tsunami evacuation scenario, a high number of tourists will bring an impact on evacuation effectiveness. This study focuses on the coastal area of Drini Beach (henceforth, referred to as Drini Coastal Area) with an

\footnotetext{
* Corresponding author: arismarfai@gadjahmada.edu
} 
absolute location at $8^{\circ} 0818.3$ "S and $110^{\circ} 3444.7^{\prime \prime} \mathrm{E}$. In Drini, the evacuation site recommended by the National Disaster Management Agency (Badan Nasional Penanggulangan Bencana-BNPB) is considered too far from the beach and ineffective. The database used by this agency for the modeling is the contour data retrieved from 1:25,000 RBI map with a contour interval (Ci) of 12.5 meters. Tsunami evacuation is a short process that has to be prepared with careful planning. Based on the calculation results, the sufficient time for the evacuation process in coastal areas in Gunungkidul is about 11 minutes [14]. DEM modeling using UAV-based photogrammetry is expected to provide an ideal recommendation for a temporary vertical evacuation site.

Drini Coastal Area is approximately $60 \mathrm{~km}$ from Yogyakarta City. It has several beaches, namely Sepanjang, Watukodok, and Drini Beach. Dry agriculture and agroforestry dominate the land use in this area. Meanwhile, the built-up environment is mainly composed of tourist facilities like shops and lodging. This combination of land use systems will lead to an enormous loss if tsunamis occur. Drini Coastal Area has an access road as a means of connection between the beaches. The presence of the road is included in the primary consideration in evacuation planning. The map of the study area and its land use is presented in Figure 1.

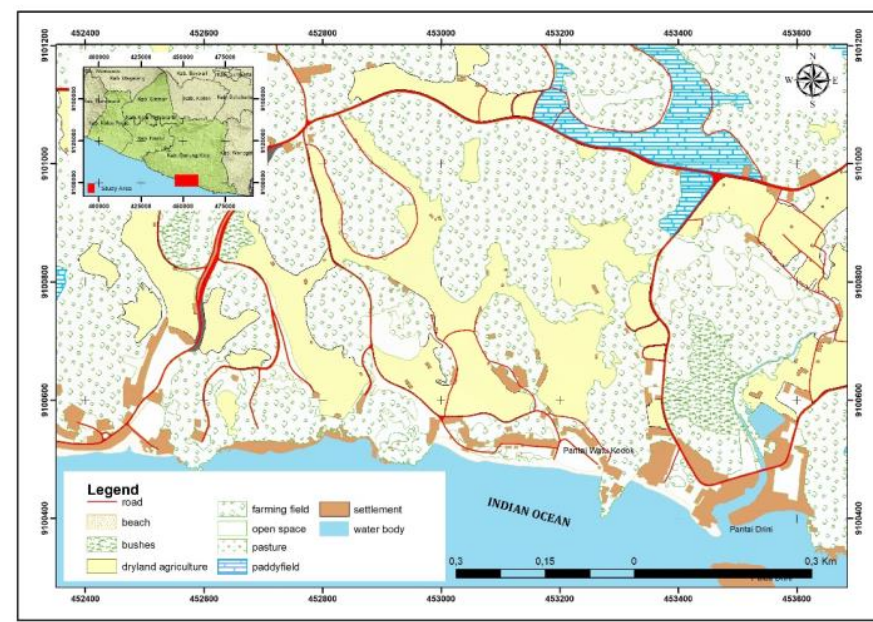

Fig. 1. Location and Land use map of Drini Coastal Area.

\section{Methods}

\subsection{Acquisition of aerial photos}

The aerial photographs were acquired using a fixed-wing aircraft with a Bixler airframe. The sensor was Canon PowerShot A2500 pocket camera with a resolution of 16 Mpix. This camera was set automatically to capture images every two seconds with a shutter speed of $1 / 2000$ to avoid blurry results on the photos and allow adequate overlap and sidelap for photogrammetry analysis. The flight route was designed at an elevation of \pm 300 meters. Ten (10) premarks were installed in the field to represent the distribution of the topographic configuration in the study area. The coordinate was identified using a geodetic Global Positioning System (GPS) using the
Real Time Kinematic (RTK) method. The aerial photograph data acquisition was conducted in March 2017. By providing the most recent DEM data based on aerial photograph, the elevation and land use data are expected to give more accurate analysis of the inundation model.

\subsection{DEM generation}

The UAV-derived photos were processed in Agisoft Photoscan. Single images with central projection were combined to form one photograph with orthogonal projection. UAV-derived photos store altitude information in pixel value. In this research, the UAV produced loose photographs that overlapped to each other and formed an image sequence with a Ground Sample Distance (GSD) of $\pm 9 \mathrm{~cm} /$ pixel, which certainly provided a highly detailed elevation for evacuation modeling and reliable data for DEM generation. A highresolution DEM is required for correcting the existing topographic data of the RBI map. DEM reconstruction resulted from photo orthorectification produced measurements with high precision [15].

Georeferencing data plot is an important process before detailed elevation modeling. This process can be performed either directly during the preparation of point cloud or indirectly after all of the data processing is completed. This research used indirect data georeferencing by inputting the coordinates identified with a geodetic GPS using the Real Time Kinematic (RTK) method. The identification was conducted at the artificial premarks. Therefore, these premarks must have easily identifiable shapes and colors on aerial photographs [16]. In addition to DEM generation from the UAV-derived photos, this research also created a comparative DEM from the contour information presented on the RBI map $(\mathrm{Ci}=12.5$ meters). This contour data was converted to DEM using the spatial analyst tools in ArcGIS 10.5.

\subsection{Tsunami inundation model}

The tsunami inundation was modeled using a raster calculator by taking into account the maximum tsunami height in Java Island, i.e., 11-13.9 meters [17,18] A height of 12 meters was selected to provide an even distribution of classes from five tsunami scenarios, namely $4,6,8,10$, and $12 \mathrm{~m}$. The inundation model involved filtering raster pixels whose values were less than or equal to 12 meters. Each pixel value in DEM raster data has altitude information [19]. Once a pixel with a predetermined value was selected, the raster was converted into a polygon. A filtering process was performed again to remove polygons that were not hydrologically connected to the shoreline using the 'select by location' command. This concept corresponds to the neighboring operation in raster data in which the unconnected pixels are not used in the analysis.

The maximum inundation model was recalculated to determine the safe area as an alternate for vertical evacuation site. Vertical evacuation sites must be higher 
than the inundation and may use more than one location like high grounds, hills, or multi-story buildings [8;20]. As proposed in Heintz (2009), the formula used to determine the height of the vertical evacuation site is presented in Eq. 1.

$\mathrm{H}_{\text {min }} \mathrm{VE}=\mathrm{H}_{\text {run up }} \mathrm{x}+30 \% \mathrm{x}\left(\mathrm{H}_{\text {run up }}\right)+3 \mathrm{~m}$

where:

$\mathrm{H}_{\min }$ vertical evacuation $=$ The minimum height of a vertical evacuation site

$\mathrm{H}_{\text {run up }}=$ The height of the maximum scenario

Furthermore, the locations that were not inundated by the maximum scenario were proposed to be the potential vertical evacuation sites. This study used several conditions to categorize the non-inundated location as an evacuation site, i.e., it is an easily accessible and not isolated place that can accommodate a large number of people [21]

\section{Results and discussion}

Orthorectification is a preliminary process in creating mosaics from single aerial photographs. In this research, the flight produced 314 photos, which were then selected using several considerations, including the percentage of overlap, brightness level, and the exclusion of blurry photos. The results of this process were orthophoto and Digital Surface Model (DSM) (Figure 2). The threedimensional modeling that used UAV-based photogrammetry had good accuracy for hydrological analysis [22]. The produced digital 3D model had a GSD of approximately $9 \mathrm{~cm}$. This spatial resolution consequently increased the reliability of DEM for the analysis.

There was a significant difference between the DEM generated from UAV-derived aerial photographs (DEMUAV) and the one created using the contour information from the 1:25,000 RBI map (DEM-RBI). DEM-RBI produced a rough topographic appearance, which would affect the inundation model. The tsunami hazard map of the BNPB uses a basic analysis of the contour data on the RBI map, which overestimates the locations of the inundated areas. Consequently, the assembly or evacuation points are not functional. Considering the evacuation time (11 minutes), these points are too far to reach on foot.

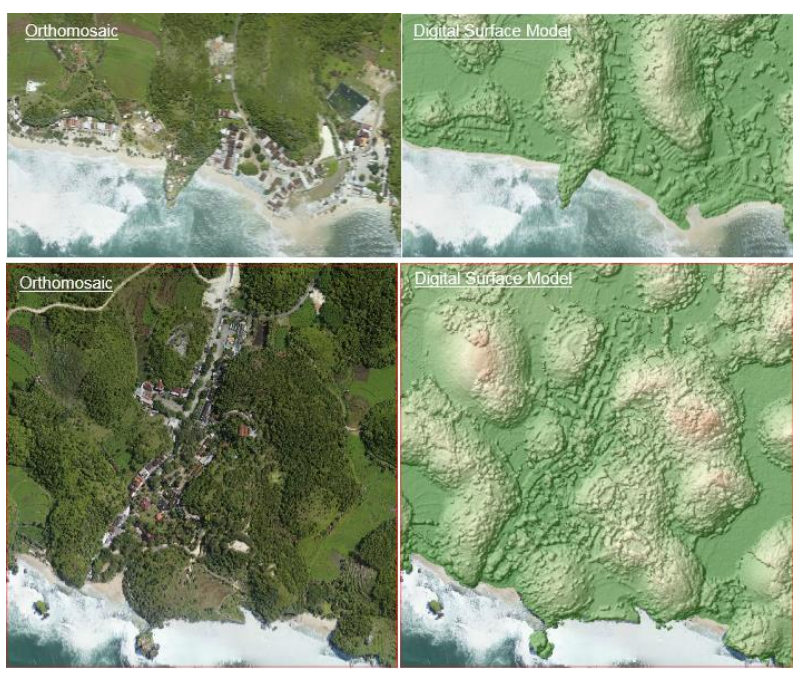

Fig. 2. Pieces of Orthomosaic (left) and DSM (right) of Watukodok-Drini Beach and Kukup Beach

The tsunami model is an inundation model whose results strongly depend on data input. The tsunami inundation was modeled with a numerical code that had to work even on the smallest cell size [23]. Therefore, data with a high spatial resolution was required to maximize the smallest cell size. DEM-UAV and DEMRBI had a significant difference regarding the results of pixel values interpolation. The distribution and the smoothness of the interpolation are observable in the generated DEM (Figure 3)

The tsunami inundation scenario used highresolution DEM to perform a precise analysis and facilitate accurately targeted disaster-based management. High-resolution models can also provide the exact picture of areas that are not affected by tsunami inundation [24]. The modeling of the maximum scenario from DEM-RBI and DEM-UAV showed a significantly different extent of the inundated area. The tsunami inundation model using the DEM-RBI produced a rough area, while the one using DEM-UAV resulted in a much smoother area. Moreover, the distribution of the inundation from the DEM-UAV-based modeling followed the topographic pattern.

The maximum inundation model using DEM-RBI and DEM-UAV had different extent of inundation and smoothness. The inundation model based on DEM-UAV covered a larger area than the one using DEM-RBI (Fig.4). The reason was the execution of the DEM-RBIbased modeling that stopped at an elevation of 12 meters because the contour above it was too high. Furthermore, the DEM-UAV-based inundation model showed a very fine or smooth result. The high spatial and temporal resolution of UAV-derived data increases the ability to respond to critical conditions where access to threedimensional information is crucial [25]. In this case, tsunami modeling requires access to $3 \mathrm{D}$ data with a high spatial resolution to maximize the outcome of tsunami hazard modeling. 

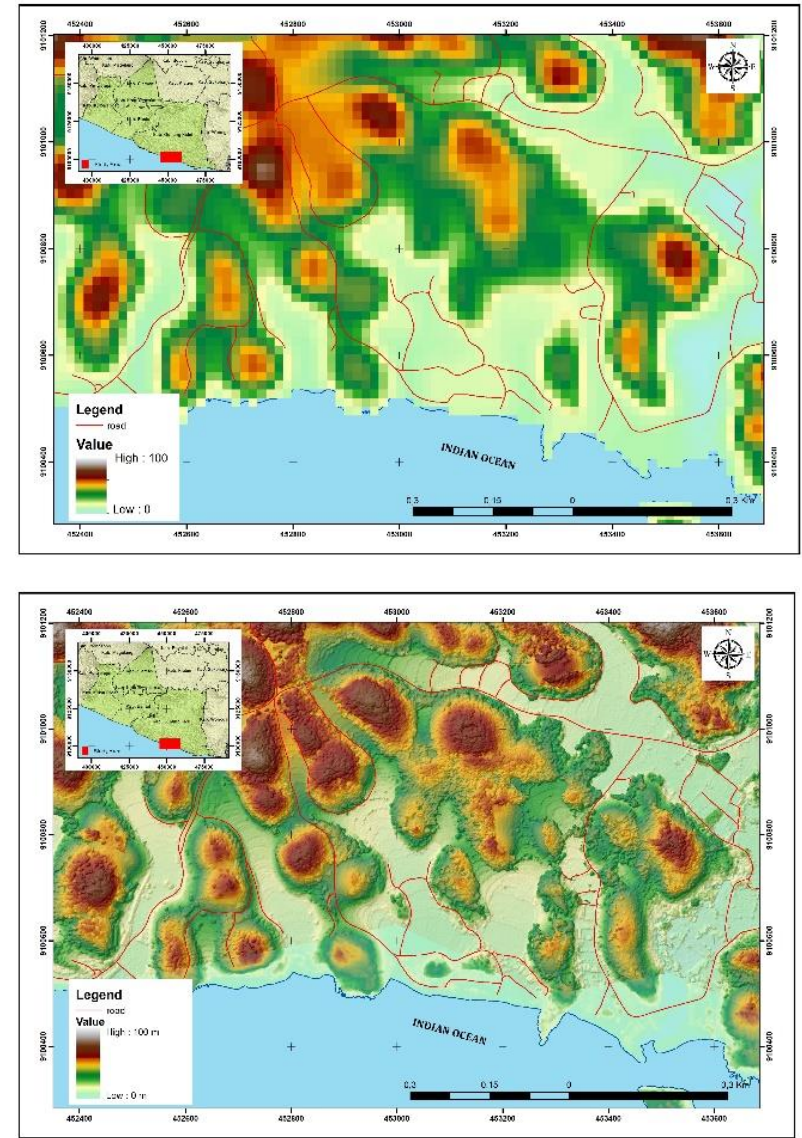

Fig. 3. The difference between DEM-RBI (above) and DEMUAV (below)

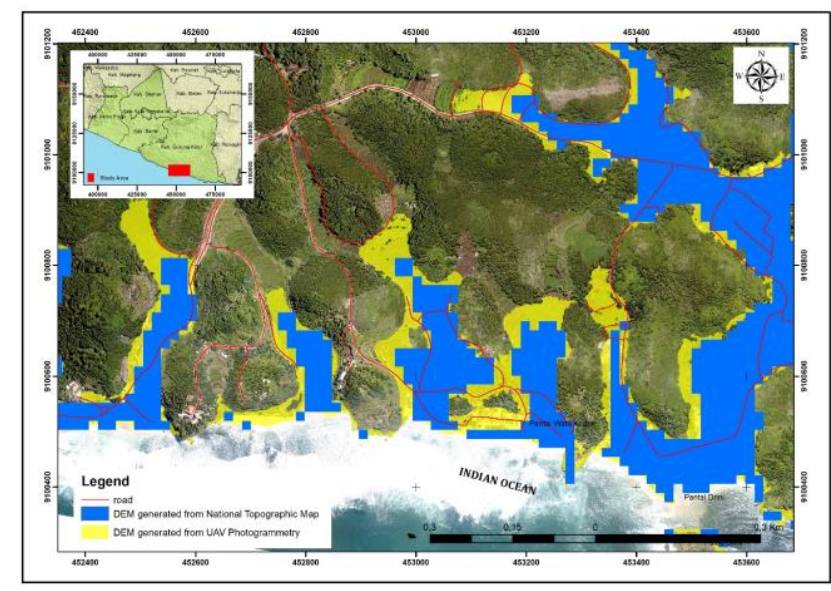

Fig. 4. The results of maximum inundation modeling with DEM-RBI (blue) and DEM-UAV (yellow)

Information about tsunami hazard and evacuation routes available to the public in the coastal area of Gunungkidul is considered not optimum. This information includes an inundation estimate using a set of data extracted from contour maps with a maximum scenario of 50 meters. Referring to tsunami events in the past, this height is an overestimation [18]. The tsunami hazard maps and evacuation routes made by BNPB make vertical and horizontal evacuations irrelevant as they exclude the limited time people have to evacuate, i.e., 11 minutes. The estimated time that the authority needs to alert people about the arrival of tsunamis is 8 minutes, and the average response time by the people on the coast is 10 minutes [26] In other words, [17] estimates that the arrival time of tsunamis is 29 minutes. The allocated time for evacuation is 11 minutes. However, the recommended safe point is $1.6 \mathrm{~km}$ from Drini Beach, and with the average speed of walking, people will reach this point in 19 minutes (Figure 5).

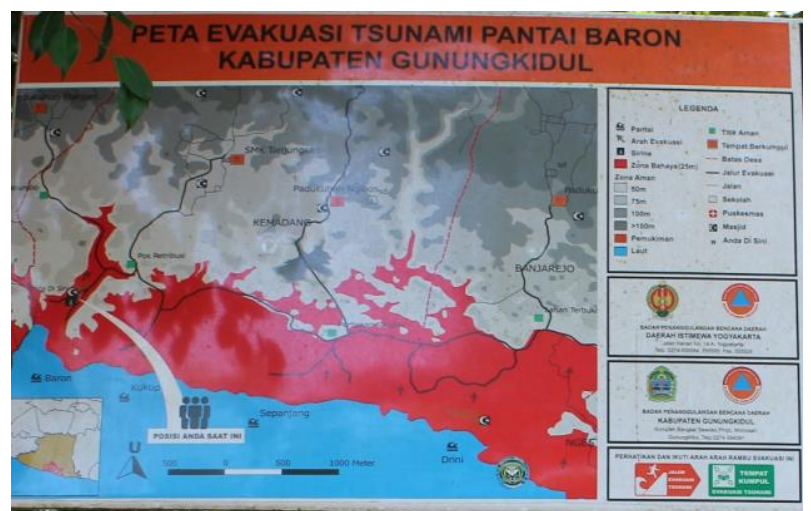

Fig. 5. The results of maximum inundation modeling with DEM-RBI (blue) and DEM-UAV (yellow)

The development of UAVs for disaster modeling has significantly improved, notably in the process of hazard and risk mapping and at the phase of emergency response [27]. The cost of UAV-derived data is relatively cheap when compared to the great importance of the output. UAV-recorded image presents actual information with a high rate of data renewal. Based on the comparison of DEM-UAV and DEM-RBI-based models (Figures 3 and 4), DEM-UAV has higher reliability as a base data for disaster management. Therefore, the determination of the vertical evacuation site in this research prioritized the use of the DEM-UAV over DEM-RBI.

The DEM-UAV-based 3D models are not only good for disaster management but also accurate for describing a detailed topographic picture of the coastal area [28]. Besides, they can periodically offer an overview of shoreline changes and dynamics, which is vital in identifying the coastline as the starting point of tsunami inundation scenario. The tsunami inundation modeling tends to use the worst-case scenario to anticipate the exposure of vulnerable areas to any inundation scenarios. This type of modeling can determine the successful implementation of early warning systems and disaster risk reduction [29].

Based on Eq. 1, the highest inundation was 17.3 meters from the coastline. As determined from DEM$\mathrm{UAV}$, the maximum scenario used in this research was 12 meters. The average elevation of the coastline, as identified from DEM, was 30 meters. Combining the highest inundation with the height of the coastline, the filter in the 'raster calculator' command included areas with less than or equal to 47.3 meters as unsafe locations [30]. The areas unaffected by tsunami inundation are cone-shaped karst hills that characterize the karstic feature in Gunungkidul Regency [31]. Even though karst hills give refraction effects on waves, they tend to be safe and, thereby, potential for external evacuation sites 
[14]. As presented in Figure 6, the blue color on the inundation model shows the maximum scenario (i.e., a 12-meter high tsunami), while the yellow one indicates the boundary of the safe location after the calculation process.

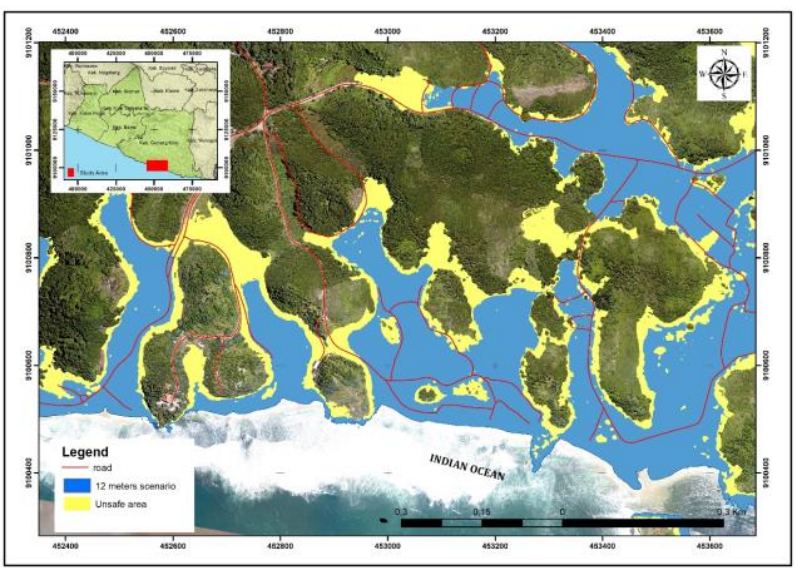

Fig. 6. The map depicting the unsafe areas from the inundation scenarios

The selection of the temporary evacuation points prioritized locations with access road. The conditions of an evacuation zone include accessibility, short but safe distance from the coast, and non-isolated area. The lack of evacuation sites in Gunungkidul Coastal Area is caused by the extensive natural cover of shrubs. The construction of ladders and structural buildings for an ideal assembly point on the hills is strongly recommended. The space required for an evacuation is 1 $\mathrm{m} 2$ per person with an estimated carrying capacity of $80 \%$ of the total area [14]. Based on the modeling results, there were six ideal locations proposed as alternative vertical evacuation sites for Drini Beach and the surrounding areas (Figure 7). Each site can accommodate up to thousands of people. The estimated extents of the vertical evacuation zone are presented in Table 1.

Table 1. The estimates of the optimal size of vertical evacuation zones

\begin{tabular}{|c|c|c|}
\hline Evacuation zones & Size $\left(\mathrm{m}^{2}\right)$ & Optimum area $\left(\mathrm{m}^{2}\right)$ \\
\hline 1 & 2074 & 1659 \\
\hline 2 & 7538 & 6031 \\
\hline 3 & 2547 & 2037 \\
\hline 4 & 3546 & 2837 \\
\hline 5 & 1331 & 1065 \\
\hline 6 & 9756 & 7804 \\
\hline
\end{tabular}

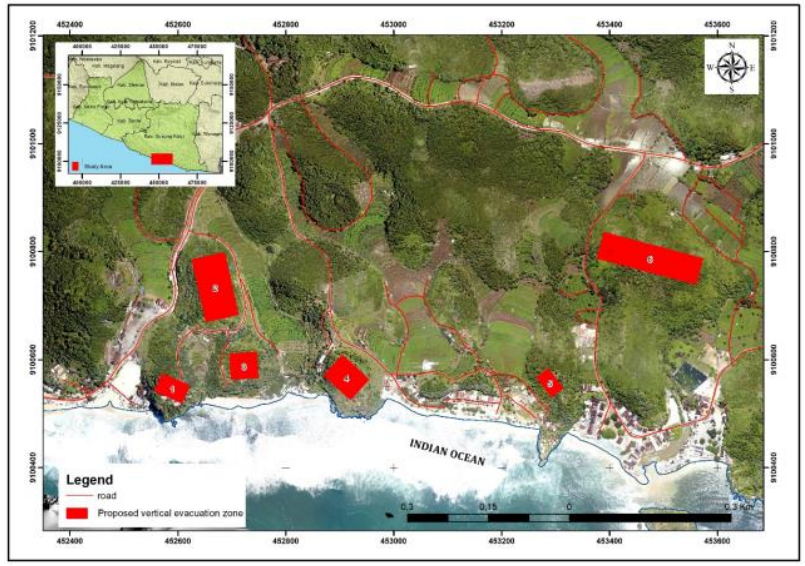

Fig. 6. Vertical evacuation zones

\section{Conclusion}

UAV technology is playing an important role in the development of spatial data information concerning the era of 4.0. UAV provides an advance solution in the development of remote sensing research. In this research, DEM and land use data were generated from UAV photogrammetry and used to model tsunami hazard respectively. These two data are accurate and, thereby, can help predict the extent of inundation and tsunami-affected areas. The DEM data generated from the UAV Photogrammetry is far more reliable than DEM-RBI. Tsunami inundation modeling in Drini coastal area is particularly suitable for predicting the extent of tsunamis impact and determine the safe area for vertical evacuation. The data can be further used as the basis for planning an evacuation route and disaster mitigation. However, the tsunami inundation model in this research requires further improvement because it has not considered the strength of tsunami waves, the time of occurrence, and time travel to the safe zone or assembly points. Future research is recommended to take into account these factors in tsunami hazard analysis.

This research is part of the Excellence Research Grant for Higher Education (Penelitian Unggulan Perguruan TinggiPUPT), titled "Pemetaan Risiko Bencana Kepesisiran menggunakan Teknologi Unmanned Aerial Vehicle (UAV) dan GIs pada Wilayah Kepesisiran Kabupaten Gunungkidul”. Authors gratefully acknowledge the research funding and support from the Indonesian Ministry of Research and Higher Education.

\section{References}

1. Engel M \& Brückner H, The Identification of Paleotsunami Deposits: a Major Challenge in Coastal Sedimentary Research, Coastline Reports 17 65-80 (2011)

2. Ö. Adyan, Seismic and Tsunami Hazard Potentials in Indonesia with a special emphasis on Sumatra Island, Journal of the School of Marine Science and Technology, Tokai University, 6(3), 19-38 (2008.)

3. Lavigne F, Gomez C, Gifo M, Wassmer P, Hoebreck C, Mardiatno D, Paris R, Field 
observations of the 17 July 2006 Tsunami in Java, Natural Hazards and Earth System Sciences 7(1) 177-183. (2007)

4. Marfai MA, King L, Sartohadi J, Sudrajat S, Budiani SR, \& Yulianto F, The impact of tidal flooding on a coastal community in Semarang, Indonesia, Environmentalist 28 237-248 (2008)

5. Okamoto T \& Takenaka H, 2009 Waveform inversion for slip distribution of the Java tsunami earthquake by using 2.5D finite-difference Green's function, Earth Planets Space, 61 17-20. (2006).

6. Sutikno, Indonesia Negeri 1001 Bencana, Paper presented at Seminar Sistem Informasi Kebencanaan sebagai Sebuah Kearifan di Negeri 1001 Bencana, Environmental Geography Student Association (EGSA), Faculty of Geography, Universitas Gadjah Mada, Yogyakarta, (2009)

7. Subandono D \& Budiman, Hidup Akrab dengan Gempa dan Tsunami, Bogor: Penerbit Buku Ilmiah Populer (2008)

8. FEMA, P646 Guidelines for design of structures for vertical evacuation form tsunamis, Federal Emergency Management Agency, Washington, D.C (2008)

9. Wood NJ, Jones J. Schelling J, Schmidtlein M, Tsunami vertical-evacuation planning in the U.S. Pacific Northwest as a geospatial, multi-criteria decision problem, International Journal of Disaster Risk Reduction 9, 68-83 (2014)

10. J. Browning, N. Thomas, An assessment of the tsunami risk in Muscat and Salalah, Oman, based on estimations of probable maximum loss, International Journal of Disaster Risk Reduction 16, 75-87 (2016)

11. Z.C. Cankaya, M.L. Suzen, A.C. Yalcineer, C. Kolat, A. Zaytsev, B. Aytore, A new GIS-based tsunami risk evaluation: MeTHuVA (METU tsunami human vulnerability assessment) at Yenikapl, Istanbul, Springer Juornal (2016)

12. Ward, P, J., Marfai, M, A., Yulianto, F., Hizbaron, D, R., Aerts, J, C, J, H., Coastal inundation and damage exposure estimation: a case study for Jakarta, Nat Hazards, 56,899-916 (2011)

13. Marfai MA, Khakim N, Fatchurohman H, Cahyadi A, Wibowo YA, Rosaji FSC, Tsunami Hazard Mapping and Loss Estimation using Geographic Information System in Drini Beach, Gunungkidul Coastal Area, Yogyakarta, Indonesia, E3S Web of Conferences 76, 03010 (2019)

14. FSC Rosaji, Pemanfaatan Teknologi Unamanned Aerial Vehicle (UAV) untuk Perencanaan Evakuasi Tsunami di Kawasan Wisata Pantai. Studi Kasus: Pantai Pulang Syawal dan Sekitarnya, Kabupaten Gunungkidul, Master Thesis, Universitas Gadjah Mada (2017)

15. Bemis SP, Micklethwaite S, Turner D, James MR, Ackcis S, Thiele ST, Bangash HA, Ground-based and UAV-Based photogrammetry: A multi-scale, high-resolution mapping tool for structural geology and paleoseismology, Journal of Structural Geology 69, 163e178 (2014)

16. Uysal M, Toprak AS, Polat N, DEM generation with UAV Photogrammetry and accuracy analysis in Sahitler hill, Measurement, 73, 539-543 (2015)

17. BNPB, Panduan Nasional Pengkajian Risiko Bencana Tsunami Indonesia, Badan Nasional Penanggulangan Bencana, Jakarta. (2011)

18. A. Suppasri, K. Goto, A. Muhari, P. Ranasinghe, M. Riyaz, M. Affan, E. Mas, M. Yasuda, and F. Imamura, A decade after the 2004 Indian Ocean Tsunami: the progress in disaster preparedness and future challenges in Indonesia, Sri Lanka, Thailand and Maldives, Pure and Applied Geophysics, 172, 3313-3341(2015)

19. Marfai MA, Khakim N, Fatchurohman H, Cahyadi A, Wibowo YA, Rosaji FSC, Tsunami hazard mapping and loss estimation using geographic information system in Drini Beach, Gunungkidul Coastal Area, Yogyakarta, Indonesia E3S Web of Conferences 76, 03010 (2019)

20. Ashar F, Amaratunga D, Haigh R, The analysis of tsunami vertical shelter in Padang city, Procedia Economics and Finance 18916 - 923 ( 2014 )

21. Trindade A, Costa PT, Catita C, A GIS-based analysis of constraints on pedestrian tsunami evacuation routes: Cascais case study (Portugal), Nat Hazard

22. Díaz-Vilariño L, González-Jorge H, MartínezSánchez $\mathrm{J}$, Bueno $\mathrm{M}$, Arias $\mathrm{P}$, Determining the limits of unmanned aerial photogrammetry for the evaluation of road runoff, Measurement 85132 141(2016)

23. Mori J, Mooney, WD, Afnimar, Kurniawan S, Anaya AI, \& Widiyantoro, Seismological Research Letters, 78 (2) 201-207 (2007)

24. B. Schneider, G. Hoffmann, Reicherter, Scenariobased tsunami risk assessment using a static flooding approach and high-resolution digital elevation data, 139, 183-194 (2016)

25. Nex F, Remondino F, UAV for $3 D$ mapping applications: a review, Appl Geomat 6:1-15 (2014)

26. Dewi, Ratna S, A-GIS Based Approach of an Evacuation Model for Tsunami Risk Reduction, IDRiM-Journal of Integrated Disaster Risk Management. ISSN: 2185-8322. DOI10.5595/idrim.2012.0023 (2012).

27. Gomez C, and Purdie H, UAV- based Photogrammetry and Geocomputing for Hazards and Disaster Risk Monitoring-A Review Geoenvironmental Disasters 3:23 (2016)

28. Gonçalves JA, Henriques R, UAV photogrammetry for topographic monitoring of coastal areas, ISPRS Journal of Photogrammetry and Remote Sensing 104, 101-111(2015)

29. J. Browning, N. Thomas, An assessment of the tsunami risk in Muscat and Salalah, Oman, based on estimations of probable maximum loss, 
International Journal of Disaster Risk Reduction 16, 75-87 (2016)

30. FEMA, P-646 Guidelines for Design of Structures for Vertical Evacuation from Tsunamis Federal Emergency Management Agency, Washington, D.C (2012)

31. Adji TN, Haryono E, Mujib A, Fatchurohman H, Bahtiar IY, Assessment of aquifer karstification degree in some karst sites on Java Island, Indonesia, Carbonates and Evaporites, 34, 1: 53-66 